\title{
Training Teachers To Use Action Research In The Classroom
}

\author{
Arsen Nahum Pasaribu ${ }^{1}$, Sondang Manik ${ }^{2}$, Erika Sinambela ${ }^{3}$, Tiara K Pasaribu ${ }^{4}$, Jubil Ezer Sihite ${ }^{5}$, Rony Arahta \\ Sembiring $^{6}$, Febrika Dwi Lestari ${ }^{7}$, Ance Juliet Panggabean ${ }^{8}$ \\ 1,2,3,4,5,6,8 Faculty of Language and Arts, Universitas HKBP Nommensen Medan, Indonesia \\ ${ }^{7}$ Faculty of Teaching Education, Universitas HKBP Nommensen Medan, Indonesia \\ ${ }^{*}$ Corresponding Author: \\ E-mail: arsen.pasaribu@uhn.ac.id
}

\begin{abstract}
.
Teachers are trained in senior high schools to increase their competence in designing and implementing CAR in the classes they teach. Seven students and eight teachers from SMAN 2 Panyabungan made up the training participants for this course. On the first day, CAR planning was stressed, and on the second day, CAR implementation was detailed. The community service was conducted by 8 lecturers of Universitas HKBP Nommensen Medan, on March 5-6, 2021. The results show that teachers' understanding of the CAR cycle had increased, however they required additional training to improve their ability to collect data and do data analysis techniques.
\end{abstract}

KeyWord: CAR, Teachers, Training, Implementation

\section{INTRODUCTION}

Classroom action research (CAR) is a type of applied research that is used in the classroom by teachers. This type of research is beneficial for resolving issues that arise during the teaching and learning process in the classroom. CAR is designed in such a way that teachers and researchers can easily apply it in an effort to, for example, determine the best method for teaching a subject in the classroom (Norton, 2018). Education experts frequently recommend the CAR model to help teachers overcome a variety of issues that arise during the teaching and learning process. CAR implementation typically takes place over the course of one semester.

Classroom action research entails a number of stages or steps in its implementation (Kemmis, McTarggart and Nixon, 2014). CAR is divided into stages that begin with planning plan, action, observation, evaluation, and reflection. Each stage must be carried out meticulously and thoroughly in order to obtain the best possible research results (Norton, 2018; Kemmis, McTarggart and Nixon, 2014). CAR is structured around research cycles, each of which includes phases of planning, action, observation, evaluation, and reflection. CAR can be conducted in multiple cycles, depending on the results of each cycle, including whether the research objectives or targets were met. If one cycle does not yield the desired results, the process can be repeated with the second cycle, and so on.

Teachers at the elementary, middle, and high school levels continue to face numerous obstacles in implementing the CAR (Pelton, 2010). Many teachers are still unaware of what CAR is or how it is implemented. This obstacle will undoubtedly impede teachers in the classroom from resolving issues, such as finding teaching methods or techniques that are compatible with the classroom characteristics of their students. As a result, low student achievement in these subjects is the end result. This is a very serious problem that must be addressed immediately. One way to address this issue is to conduct CAR implementation training for elementary, middle, and high school teachers. As a result, we, as lecturers at HKBP Nommensen University, are being asked to provide community services for high school teachers (SMA) in order to increase teachers' ability/competence in implementing CAR in their school. 
This community service project was implemented for the teachers of SMA Negeri 2 Penyabungan, Mandailing Natal Regency. This training will be attended by eight teachers from SMAN 2 Payabungan. According to the results of the interview method used to identify problems prior to the implementation of the training, the teachers at SMAN 2 Payabungan continue to face a variety of issues related to the implementation of CAR. Teachers generally lack an understanding of how to implement each stage and cycle of CAR. What are the steps involved in implementation? What data collection techniques are used. Despite the difficulties they face in implementing CAR, it is hoped that this training will assist teachers in enhancing their abilities and competencies in implementing CAR in their classrooms.

\section{METHODS}

This classroom action research application training is designed to increase teachers' ability to implement CAR in their classrooms. SMA Negeri 2 Panyabungan hosted this training. This two-day training session was conducted via Zoom. Zoom was used in response to an outbreak of the Covid-19 disease in Indonesia. The government has placed restrictions on population movement in order to prevent the COVID-19 virus from spreading further. As a result, face-to-face instruction is not possible. This training took place on March 5-6, 2021, at SMA Negeri 8 Payabungan, Mandailing Natal Regency, and was attended by eight teachers. While at HKBP Nommensen University, the Community Service program was implemented by eight lecturers.

This CAR training is divided into 4 stages: (1) Preparation; (2) Implementation; (3) Evaluation; (4) Reporting.

1. Preparation

During the preparation stage, all team members discussed the task assignment for implementing this community service. These responsibilities include the development of training materials, training planning, gathering information about teachers' CAR competence through interviews, preparing training facilities such as the use of Zoom, and developing and reporting on community service evaluation instruments.

2. Implementation

The community service implementation team identified issues, specifically the barriers to CAR implementation faced by teachers at SMA Negeri 2 Pengabungan. This identification was accomplished through the use of Zoom media to facilitate collaboration between teachers and the community service implementation team. The CAR training implementation team used this forum to interview teachers about the barriers they encountered while implementing CAR. The interview was conducted in an informal and very friendly manner, allowing for an open exchange of questions and answers between the teachers and the community service implementation team. Things that concern the community service implementation team as they identify issues that teachers face when implementing CAR.

3. The third stage is to assess the training's success. The evaluation is conducted through the distribution of a questionnaire with a likert scale model containing statements describing the progress made by teachers in implementing CAR. This evaluation took place on the second day, at the conclusion of the training.

4. The final stage is to create a community service report that includes information about the implementation of community service, community service materials, and the evaluation results.

\section{RESULTS AND DISCUSSION}

The implementation of teacher training in conjunction with the application of CAR resulted in significant improvements in the ability of teachers at SMA Negeri 2 Payabungan. Prior to the implementation of community service, teachers encountered a number of roadblocks. Conducting interviews with teachers to ascertain the obstacles they face in implementing the CAR revealed the following table. 
Tabel 1. Obstacles to CAR implementation encountered by teachers

\begin{tabular}{|c|l|c|}
\hline No & \multicolumn{1}{|c|}{ Obstacle faced by teachers in implementing CAR } & Number of teacher \\
\hline 1 & Teachers are unfamiliar with CAR & 6 \\
\hline 2 & Teachers lack an understanding of how to conduct CAR planning. & 8 \\
\hline 3 & Teachers do not comprehend every step of the CAR process. & 8 \\
\hline 4 & $\begin{array}{l}\text { Teachers do not comprehend how to conduct tests and gather data } \\
\text { in CAR. }\end{array}$ & 6 \\
\hline 5 & $\begin{array}{l}\text { Teachers are unfamiliar with the interviewing technique used to } \\
\text { collect data for the CAR. }\end{array}$ & 6 \\
\hline 6 & $\begin{array}{l}\text { Teachers are unfamiliar with the method of observation used to } \\
\text { collect data in CAR. }\end{array}$ & 6 \\
\hline
\end{tabular}

The results of interviews conducted prior to the training are shown in Table 1. The interview results are quite surprising, as almost all teachers are unfamiliar with classroom action research and thus do not understand how to design and implement a CAR. The majority of teachers who attended the training were unfamiliar with the CAR's data collection methods, whether quantitative (test) or qualitative (observation and interview).

The training lasted two days, with the first day focused on the description, function, planning, and implementation of CAR. Meanwhile, on the second day, teachers received training with an emphasis on CAR implementation practices, with the assistance of students from State High School 2 Payabungan via a blended learning system. The second stage involves teachers attempting to implement the Classroom action research they have designed. Following the CAR simulation, an evaluation is conducted using a likert scale at the conclusion of the training.Evaluation is conducted to ascertain the degree to which the training was successfully implemented. Whether teachers understand how to design, implement, and assess. The following conclusions were drawn from the evaluation conducted following the two-day CAR design and implementation training.

Tabel 2. Results of evaluation of CAR Training

\begin{tabular}{|c|l|c|c|}
\hline No & \multicolumn{1}{|c|}{ Evaluation results of CAR training } & Score & Percentage \\
\hline 1 & $\begin{array}{l}\text { Teachers are aware of the CAR's existence and } \\
\text { functions. }\end{array}$ & $40 / 50$ & $80 \%$ \\
\hline 2 & $\begin{array}{l}\text { Teachers are aware of how to conduct CAR } \\
\text { planning. }\end{array}$ & $38 / 50$ & $76 \%$ \\
\hline 3 & $\begin{array}{l}\text { Teachers are aware of how to implement CAR into } \\
\text { each cycle. }\end{array}$ & $36 / 50$ & $72 \%$ \\
\hline 4 & $\begin{array}{l}\text { Teachers are familiar with the CAR data collection } \\
\text { process. }\end{array}$ & $33 / 50$ & $66 \%$ \\
\hline 5 & $\begin{array}{l}\text { Teachers are familiar with the CAR data analysis } \\
\text { process. }\end{array}$ & $32 / 50$ & $64 \%$ \\
\hline
\end{tabular}

The results of the evaluation of teacher training at SMAN 2 Payabungan in terms of planning and implementing CAR are shown in Table 2. The questionnaire results indicate that the teachers at SMAN 2 Payabungan already have a strong grasp of CAR and its functions. This is demonstrated by the fact that $80 \%$ of teachers have an excellent understanding. Then the teachers will also be able to design a reasonably good CAR (76\%). Teachers reported that they were 72 percent aware of the CAR cycle's implementation. As many as $66 \%$ of teachers stated that they understood how to collect data in Classroom action research. Finally, teachers believe that they still do not understand how to conduct data analysis. This statement represented 64 percent of the data collected.As evidenced by the results of the teacher training in planning and implementing CAR at SMAN 2 Payabungan, teachers already possess a strong understanding of classroom action research and the CAR's function. To improve the quality of teachers' instructional methods and techniques in the classroom, it is necessary to conduct simple and practical research to determine the extent to which the instructional methods and techniques used by teachers are effective and well-liked by students (Levin, 1999). Classroom action research can undoubtedly document this. Additionally, teachers have a solid understanding of how to design classroom action research. This ability is deemed critical for teachers to possess prior to the CAR's 
implementation (Meesuk, Sramoon and Wongrugsa, 2020). The CAR design process encompasses the CAR cycle plan, the materials and methods used, the time and location of the CAR, the data collection techniques used, and the data analysis techniques used.

Before the CAR cycle can begin, it is critical for teachers to understand how it will be implemented (Phillips and Carr, 2014; Burns, 2010). The evaluation of teacher training revealed that the majority of teachers are already familiar with the CAR cycle. They believe they have a firm grasp on the process of carrying out a series of CAR actions, beginning with planning, action, observation, and evaluation and reflection. This statement, however, somewhat contradicts the statement that they lack an understanding of how to collect and analyze data in classroom action research. As we all know, data collection and analysis are inextricably linked to other CAR activities. In other words, data collection and analysis are an integral part of each CAR cycle. As a result, it can be inferred that teachers' proficiency in implementing each CAR cycle is still lacking. As a result, future training on CAR planning and implementation for teachers at SMAN 2 Payabungan is still considered necessary to strengthen teachers' understanding and competence in implementing CAR. In the future, training can be focused on improving understanding and implementation of CAR by emphasizing data collection techniques and also data analysis methods, both quantitative and qualitative.

\section{CONCLUSION}

Classroom action research planning and implementation training for teachers at SMAN 2 Panyabungan is deemed necessary due to the teachers' current lack of understanding of CAR and how to implement it. As a result, the HKBP Nommensen University's Community Service Team (CST) provided community service by training teachers in the design and implementation of CAR. The training took place over two days, with the first day devoted to CAR planning and the second to CAR implementation. Following the training, an evaluation is conducted to determine the degree of success of the research. The evaluation findings indicate that the CAR planning and implementation training for teachers at SMAN 2 Panyabungan was a success, although some teachers continue to struggle with data collection and analysis. As a result, similar training should be repeated with the same participants in the future, particularly with regard to mastery of data collection techniques and CAR data analysis. This will increase teachers' confidence in implementing CAR in their classrooms.

\section{ACKNOWLEDGEMENTS}

The community service implementation team of HKBP Nommensen University would like to thank everyone who contributed to the success of this community service at SMAN 2 Panyabungan, particularly the principal, who granted permission, time, and location for this training.

\section{REFERENCES}

[1] Burns, A. (2010) Doing Action Research in English Language Teaching. First. New York: Routledge. doi: $10.4324 / 9780203863466$.

[2] Kemmis, S., McTarggart, R. and Nixon, R. (2014) The Action Research Planner. First. Singapore: Springer.

[3] Levin, M. (1999) 'Action Research Paradigms', in Greenwood, D. J. (ed.) Action Research: From practice to writing in an international action research development program. First. USA: John Benjamins North America, p. 294.

[4] Meesuk, P., Sramoon, B. and Wongrugsa, A. (2020) 'Classroom Action Research-based Instruction: The Sustainable Teacher Professional Development Strategy', Journal of Teacher Education for Sustainability, 22(1), pp. 98-110. doi: 10.2478/jtes-2020-0008.

[5] Norton, L. (2018) Action Research in Teaching and Learning. First, Taylor \& Francis. First. New York: Routledge. doi: 10.4324/9781315147581.

[6] Pelton, R. P. (2010) Action Research for Teacher Candidates. first. New York: Rowman \& Littlefield Education.

[7] Phillips, donna K. and Carr, K. (2014) Becoming A Teacher Through Action Research. Third. New York and London: Routledge. 